\title{
IDENTIFICATION OF GROUNDWATER CONTAMINATION USING 2-D ELECTRICAL IMAGING SURVEY
}

\author{
Rafael Machado Mello ${ }^{1}$, Carlos Tadeu Carvalho do Nascimento², \\ Sergio Koide ${ }^{3}$ and João Cândido Magalhães ${ }^{4}$
}

\begin{abstract}
In February, 2009, an underground industrial effluent discharge originating from a small meat processing industry was identified in Ceilândia, Distrito Federal, Brazil. The contamination plume reached the phreatic level, where it propagated reaching the wells located downstream the discharge point. The area near this effluent discharge point was monitored by monthly groundwater sampling and analysis. In January, 2011, a geophysical survey was carried out in this area, using the DC electrical resistivity method. Three resistivity sections were obtained and they allowed the mapping of the contamination plume. The contaminated spots presented resistivity values less than 140 Ohm.m and non-contaminated areas showed values between 140 and 2550 Ohm.m. The three sections were numerically integrated and the result was a 3-D figure showing the volume of subsurface with lower values of resistivity. The study showed reduced resistivity values in a portion of the subsoil out of the expected contaminated area, which suggests the existence of another contamination source.
\end{abstract}

Keywords: resistivity, pollution, industrial effluent.

RESUMO. Em fevereiro de 2009, em Ceilândia, Distrito Federal, foi identificado um lançamento de efluente industrial no subsolo derivado do processamento, lavagem, tratamento e embalagem de carnes. A pluma de contaminação chegou ao lençol freático onde se propagou até atingir poços e cisternas situadas a jusante do ponto de lançamento. A região onde ocorreu este lançamento passou a ser monitorada por meio de coleta mensal e análise de amostras da água subterrânea. Em janeiro de 2011 foi feito um levantamento geofísico na área utilizando o método elétrico de corrente contínua. Foram obtidas três seções de resistividade que possibilitaram mapear a pluma de contaminação. As regiões contaminadas apresentaram valores de resistividade inferiores a 140 0hm.m, enquanto aquelas não contaminadas mostraram valores entre 140 e 2550 Ohm.m. As três seções foram integradas numericamente e o resultado foi uma figura tridimensional que envolve 0 volume da subsuperfície com os menores valores de resistividade. 0 estudo mostrou valores reduzidos de resistividade em uma parte do subsolo fora da área de influência da pluma de contaminação conhecida, sugerindo a existência de outro foco de contaminação.

Palavras-chave: resistividade, poluição, efluente industrial.

\footnotetext{
1ADASA, Parque Ferroviário de Brasília, Estação Rodoferroviária, 70631-900 Brasília, DF, Brazil. Phone: +55(61) 3961-4985 - E-mail: rafael.mello@adasa.df.gov.br

2 Universidade de Brasília, Faculdade UnB Planaltina, 73345-010 Planaltina, DF, Brazil. Phone: +55(61) 3107-8052 - E-mail: carlostadeu@unb.br

3 Universidade de Brasília, Departamento de Engenharia Civil e Ambiental, 70910-900 Brasília, DF, Brazil. Phone: +55(61) 3107-0926 - E-mail: skoide@unb.br

${ }^{4}$ Universidade de Brasília, Instituto de Geociências, 70910-900 Brasília, DF, Brazil. Phone: +55(61)3631-7537 - E-mail: candido.magalhaes@hotmail.com
} 


\section{INTRODUCTION}

Monitoring the groundwater quality in Distrito Federal (DF) is greatly important, since the demand for this water is growing rapidly due to urban expansion. The case study relates to an irregular discharge of effluent resulting from washing, processing and packaging steps of a small meat processing plant located in Ceilândia. The effluent was discharged into an uncoated cesspool and reached the phreatic surface, spreading into the groundwater. The company is located near residential lots, of which several showed contamination of wells and cisterns. There is also the risk of the pollutants reaching the source of the Capão do Brejo stream, a tributary of the Descoberto River. Geophysical surveys employing the direct current electrical resistivity method were performed, in order to identify the effluent spreading pattern in the subsurface, especially close to the residential lots.

\section{CHARACTERIZATION OF THE STUDY AREA}

\section{Location and description of the pollution source}

This work was developed in the Bela Vista Rural Condominium, in Ceilândia, a town with approximately 400,000 inhabitants (Fig. 1) in the Distrito Federal. Wells are the only source of water for households and industries in this area and in the condominium. The study area is located in the headwaters of the Capão do Brejo stream, a tributary of the Descoberto River subbasin, Parnaíba Basin. This is an area of 350 hectares, characterized by irregular land occupation. There are approximately 500 houses located within the catchment area of the Capão do Brejo stream.

Small industries, including meat processing, are located inside this area. In one of these small industries, the soil was infiltrated by the industrial effluent resulting from washing, processing and packaging of meat for making beef jerky. Sodium chloride is the main product used in the process; therefore, the effluent consists basically of the mixture of brine and blood of the processed meat. This effluent has high levels of chloride and Biochemical Oxygen Demand (BOD) and cannot be disposed of without treatment. For this reason, the industry has built a system for biological treatment of wastewater that consists of decanters, aerators, and sand and gravel filters. This system should treat two cubic meters of effluent per day, with BOD higher than 2,300 mg/liter; chlorides, 50,000 mg/liter; and total ammonium nitrogen above $83 \mathrm{mg} / \mathrm{l}$. The treatment system failed at some point in time as the effluent disposed on the ground through a cesspool showed no significant reduction of polluting load. These effluents reached the phreatic surface, eight feet deep, and propagated following the hydraulic gradient, reaching wells and cisterns of households located downstream of the company.

The cisterns nearby the small plant showed the presence of a substance similar to the effluent produced by the company. From that moment, the Agência Reguladora de Águas, Energia e Saneamento Básico do Distrito Federal, ADASA, (Regulatory Agency for Water, Energy and Sanitation of the Federal District), responsible for the management of water resources in DF has prohibited the wastewater treatment system for suspected inefficiency. The area is being monitored by the agency through physico-chemical and bacteriological analyses of groundwater and wastewater. The contamination was identified in February 2009, and in January 2011, a geophysical survey was performed at the site to identify possible contaminated underground areas.

\section{Geology}

The Distrito Federal is located in a regional high with no major surface drainage, being a natural divider of three major watersheds and for this reason the groundwater is of strategic importance for the supply of rural and urban areas. In this region there are two groups of aquifers, called Fractured and Porous Domains. The first group consists of rock units where the water occupied spaces are represented by planar discontinuities. The second corresponds to soils, alteration mantle rocks and alluvial materials, in which the water occupies the intergranular spaces (Campos \& Freitas-Silva, 1998).

The Fractured Domain is associated with four distinct lithologic groups that make up the regional geological context of the Distrito Federal: Paranoá, Canastra, Araxá and Bambuí groups. The Paranoá group, aged from Meso to Neoproterozoic, occupies $65 \%$ of the total area of the Distrito Federal and in this region, it can be divided, from base to top, into six lithostratigraphic units: meta-siltstone, slate, sandy metarhythmite, quartzite, clayey metarhythmite and psammo-pelitic-carbonated unit. The groundwater of the Fractured Domain presents understated risk of contamination since the overlapped aquifers of the Porous Domain act as a natural filter (Campos \& Freitas-Silva, 1998).

The Porous Domain in the Distrito Federal corresponds to shallow and free aquifers, with extensive lateral continuity, usually availed by shallow wells. These aquifers are moderately susceptible to contamination by external agents. This Domain can be divided into systems based on hydraulic conductivity and thickness. In the study area, the predominant P1 system corresponds to Oxisol, resulting from weathering of the clayey metarhythmite (Campos \& Freitas-Silva, op. cit.). 


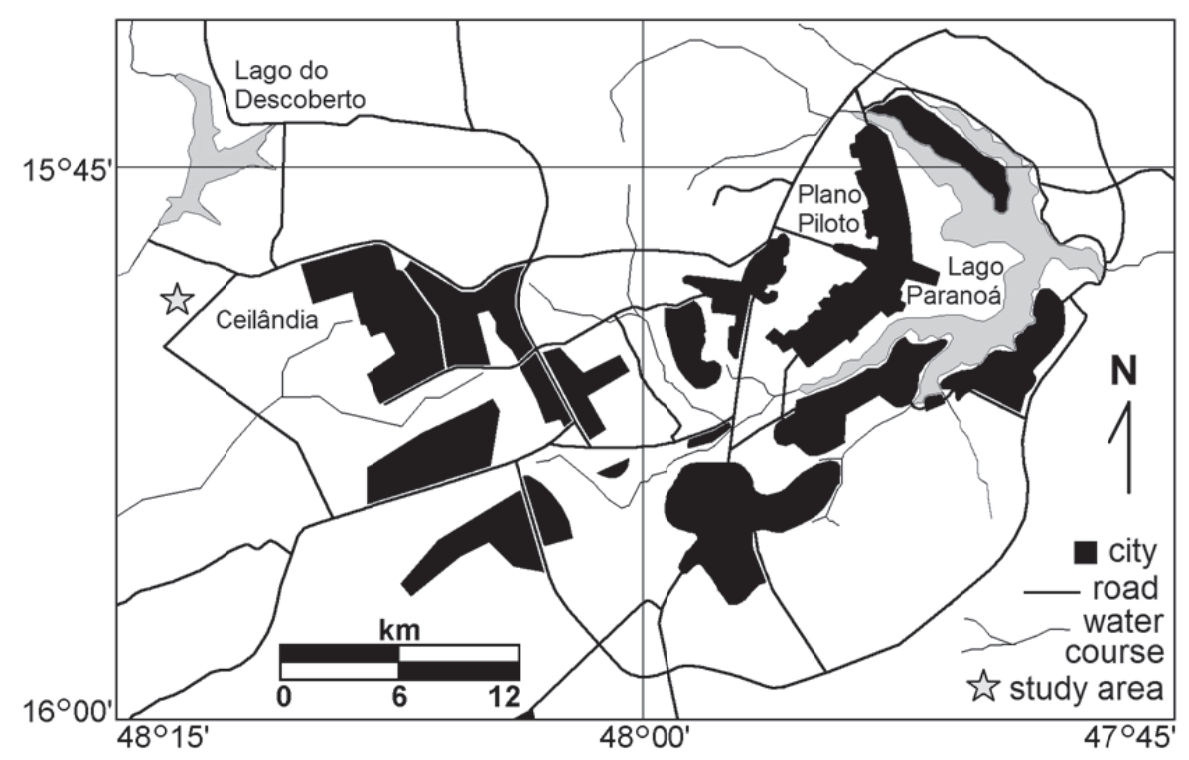

Figure 1 - Location of the study area.

\section{METHODOLOGY}

\section{Theoretical review}

The first successful attempts to use the resistivity as a tool for mineral exploration date from the early twentieth century. The rocks and soils, in general, are very resistive, but the presence of metallic substances, of natural or anthropogenic origin, may favor the passage of electric current. This fact led to the idealization of this method, initially for exploring metallic minerals, but during the second half of the twentieth century, the most common applications were those associated with groundwater, because the presence of water in the pores and/or fractures commonly reduces resistivity.

At first, prospecting of the underground water was tied to the oil industry since it could facilitate the detection of structural traps. Subsequently, this geophysical method was used to search for groundwater and, since the mid-twentieth century, for monitoring the contamination of aquifers (Van Nostrand \& Cook, 1966; Orellana, 1972; Telford et al., 1985).

Although the electrical resistivity of soils and rocks depends on many factors such as porosity, soil or rock composition, particle orientation and shape, and pore structure (Keller \& Frischkecht, 1966; Parkhomenko, 1967), an important marker is the electrical resistivity of the fluid contained in the pores (water in particular). On the other hand, water resistivity tends to decrease with increasing dissolved solids (natural mineralization or addition by pollution). Pollution, therefore, can lead to a substantial decrease of rock resistivity.
There are a number of publications showing how the resistivity can be used to identify or delimit polluted regions within the saturated zone. Generally, these works are carried out near garbage dumps and landfills, where contaminant plumes can occur. These plumes tend to migrate to the subsurface, interacting with the soil and eventually reaching the saturated zone. The difference between the electrical properties of the aquifer, saturated either with native water or different proportions of pollutant liquid, enables to delimit the polluted area (Mazac et al., 1987; Ellert et al., 1990; Meju, 1993; Costa \& Ferlin, 1993; Matias et al., 1994; Frohlich et al., 1994; Costa et al., 1995; Nascimento et al., 1999a,b; Meju, 2000).

The direct current electrical resistivity method usually works with two current ( $A$ and $B$ ) and two potential ( $M$ and $N$ ) electrodes, all of them fixed onto the soil surface. A potential differential is applied between the electrodes $A$ and $B$ and, as a result, a direct electrical current travels through the soil. The current value is measured and recorded. The electrodes $\mathrm{M}$ and $\mathrm{N}$ are used to measure the potential difference that is established on soil and associated with the travelling current. It is noteworthy that the soil already has a natural electric potential, called spontaneous potential, which must be subtracted from the measurement between electrodes $\mathrm{M}$ and $\mathrm{N}$. Knowing the current that travels the subsoil, the electrodes arrangement geometry and the potential measured between electrodes $\mathrm{M}$ and $\mathrm{N}$ allows to calculate an apparent electrical resistivity value named as such because it is measured in a heterogeneous and anisotropic medium as a function of the electrode array (Orellana, 1972; Telford et al., 1985). 
In the horizontal electrical profiling, also known as resistivity measurements, the four electrodes are moved in groups on the ground to obtain a set of measures regularly distributed along a given direction. When several measurement lines are performed in a given area, the results can be presented in the form of maps. The investigation depth depends on the spacing between the electrodes, signal to noise ratio, and local electrical properties, among others.

Since the mid-1980s, several automated devices to perform horizontal electrical profiling became available on the market, thus reducing the operating time. The common feature of such devices is the use of multiple electrodes connected independently that are activated or deactivated by means of a microcomputer to simulate the displacement of only four electrodes with different spacing on the ground.

This resistivity measuring device enables acquiring hundreds of resistivity measurements at different depths and throughout the area where the electrodes are placed. The large volume of data enables to present them as pseudo-sections, graphical representations of the resistivity variation in the subsurface in two dimensions, length and pseudo-depth. This type of work has been called 2-D electrical imaging and provides good results in areas of complex structure, where conventional electrical profiling is inadequate.

The development of 2-D electrical imaging equipment was accompanied by the development of specific computer software to represent this type of measurement, such as RES2DINV (Loke \& Barker, 1995, 1996). This software inverts the set of measures, i.e., allows to build a subsurface geoelectrical model, whose response to the energization reproduces, as best as possible, the measurements obtained. This geoelectrical model is subsequently interpreted in terms of the geological/hydrogeological/pedological model that fits best the studied area.

\section{Technique and performed tests}

The geophysical equipment used during the field work was the SYSCAL Pro resistivity meter, manufactured by Iris Instruments, France (Fig. 2). This device combines transmitter and receiver in a single module, powered by a $12 \mathrm{~V}$ battery and whose specifications include output voltage up to $1000 \mathrm{~V}$. The SYSCAL Pro is a multichannel equipment, which allows multiple potential dipoles to be used simultaneously to obtain the resistivity measurements.

The dipole-dipole arrangement allows fairly quick data acquisition, and enables studying the lateral variation of a given physical parameter at different depths. This arrangement has the current
$(\mathrm{AB})$ and the potential (MN) dipoles, which are most commonly placed linearly on the ground. The spacing between $A$ and $B$ is equal to the spacing between $\mathrm{M}$ and $\mathrm{N}$ both of which remain unchanged during data acquisition. The distance between dipoles is an integer multiple of the spacing between the electrodes that form a dipole, and should vary during acquisition. Greater depths are reached by increasing the distance between the dipoles. The measurements are plotted at the intersection of lines starting from the centers of the current and voltage dipoles, and form a 45degree angle with the horizontal (Fig. 3). Equation (1) is used to calculate the apparent electrical resistivity.

$$
\begin{aligned}
\rho_{a} & =K \cdot R \\
K & =a \cdot \pi \cdot n \cdot(n+1) \cdot(n+2) \\
R & =\frac{\Delta U}{I}
\end{aligned}
$$

$$
\begin{aligned}
\rho_{a}= & \text { apparent resistivity }(\text { Ohm.m) } \\
K= & \text { geometry factor for the used array }(\mathrm{m}) \\
R= & \text { electrical resistance }(0 \mathrm{hm}) \\
a= & \text { spacing between electrodes which form a dipole }(\mathrm{m}) \\
n= & \text { multiple of the distance between the dipoles } \\
& \text { (typically } n=1,2,3,4,5 \text { and } 6) \\
\pi= & 3.1415 \\
\Delta U= & \text { electric potential difference }(\mathrm{mV}) \\
I= & \text { electric current }(\mathrm{mA})
\end{aligned}
$$

Three lines of investigation were performed. Line 1 was 215 meters long, located upstream from the meat processing plant; Line 2 was 135 meters long, parallel to line 1, positioned immediately downstream from the plant; and, Line 3 was 180 meters long, parallel to the other two and positioned 70 meters downstream from the plant. Data with dipoles of 5, 10 and 15 meters for 10 different levels (Fig. 4) were acquired in each section.

\section{Data processing}

The data have been processed jointly using the RES2DINV software (Loke \& Barker, 1995, 1996). This software adopts a rapid technique for inverting apparent resistivity data into actual resistivity, which is much more useful for geological interpretation. Theoretically, it produces a subsurface geoelectrical 2-D model free of the distortions from the pseudo-sections of apparent resistivity caused by the geometry array used (Loke \& Barker, op. cit.). The average depth of 37 meters was reached in the three sections, calculated by the Edwards depth model (1977) adopted by the RES2DINV software. 


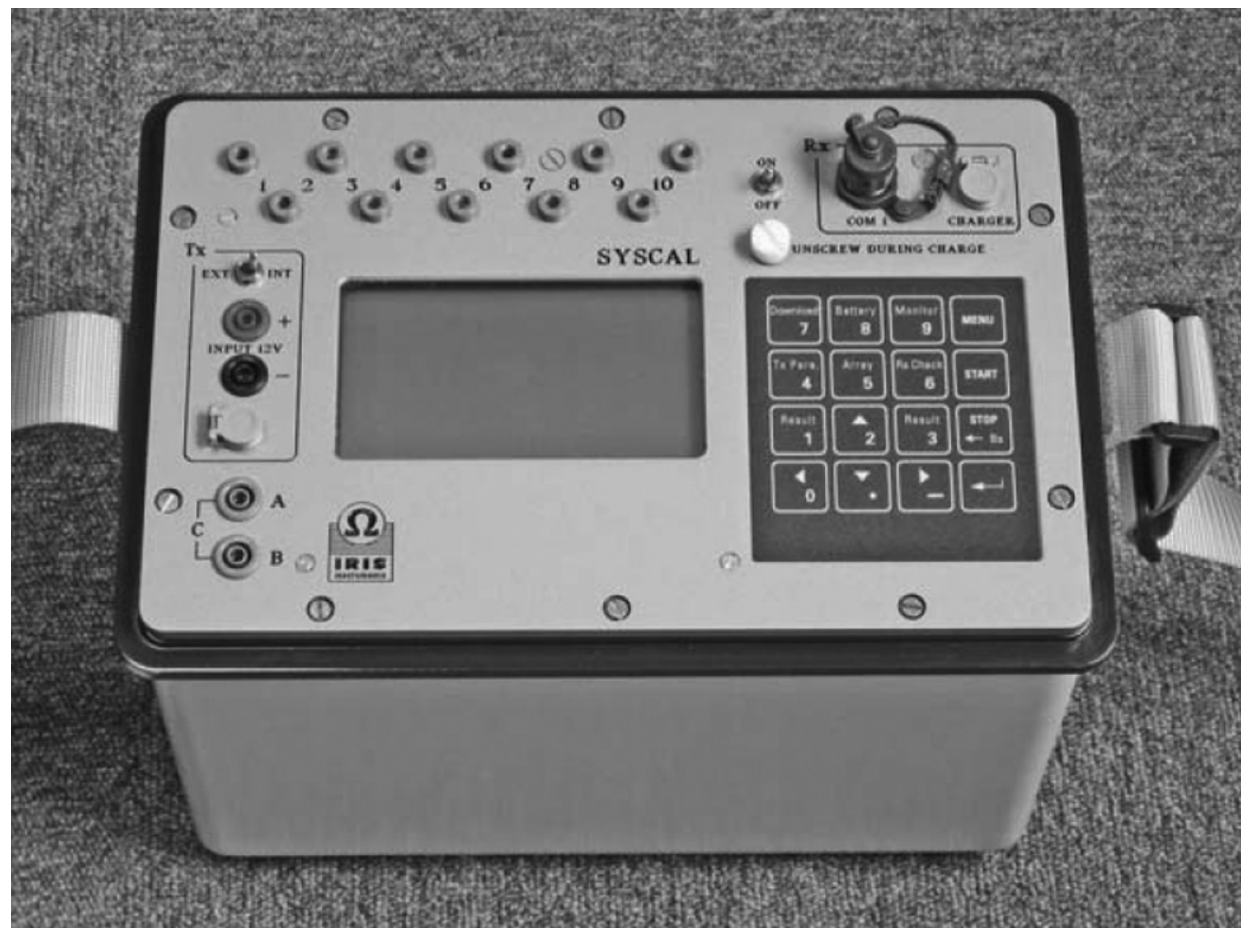

Figure 2 - SYSCAL Pro resistivity meter manufactured by Iris Instruments, France.

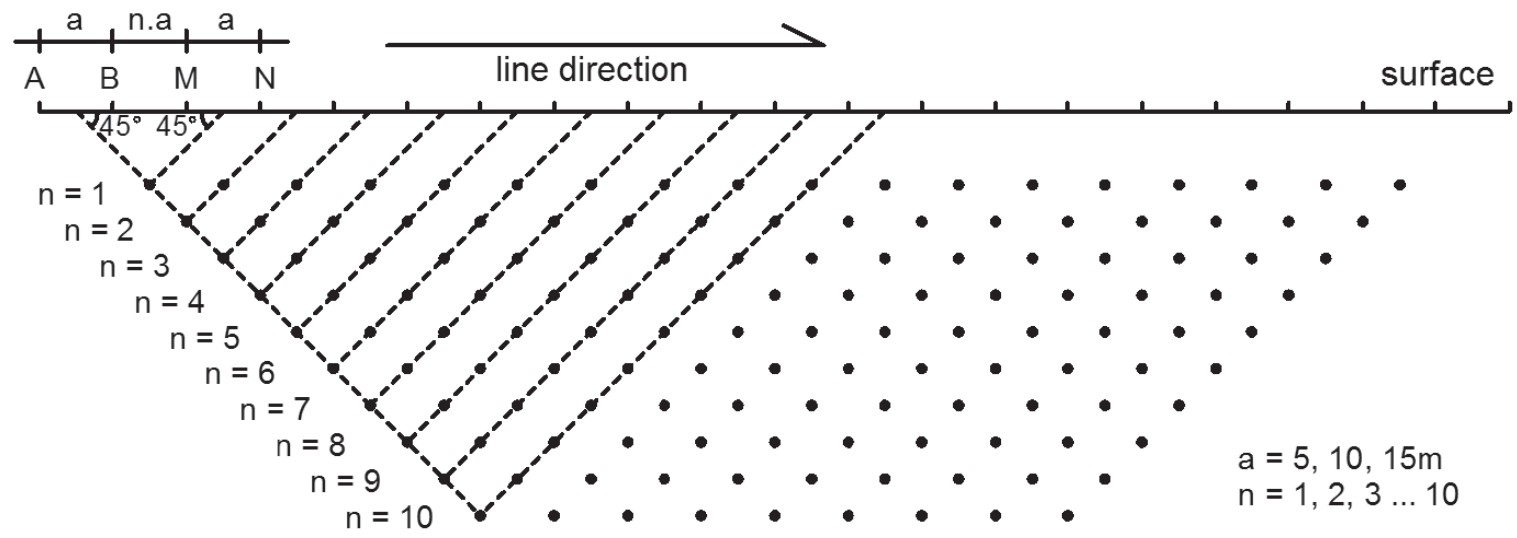

Figure 3 - Schematics of data acquisition using the dipole-dipole (DD) array at 10 different depths.

\section{RESULTS AND DISCUSSION}

The apparent resistivity values obtained ranged from 223 to 2298 Ohm.m on Line 1; from 5 to 1873 Ohm.m on Line 2; and from 3 to 2546 Ohm.m on Line 3. Line 1 was located upstream of the area affected by the meat processing plant effluent, while lines 2 and 3 were downstream; therefore, higher resistivity values were expected on line 1. Furthermore, because line 2 was located immediately downstream from the point where the effluent was released the lowest resistivity values were expected on this line.
The apparent resistivity measurements were interpreted using the RES2DINV software and the corresponding sections are shown in Figures 5, 6 and 7. The resistivity values indicative of contamination adopted for these sections were less than $140 \mathrm{Ohm} . \mathrm{m}$, since these values were only found in places where contamination was observed. Thus, the values between 140 and 2550 Ohm.m were considered to be associated with areas without contamination. Visual analysis showed a contaminated zone on line 1, at 80 meters. However, values indicative of a contaminant plume were not expected on this line because the plume on 


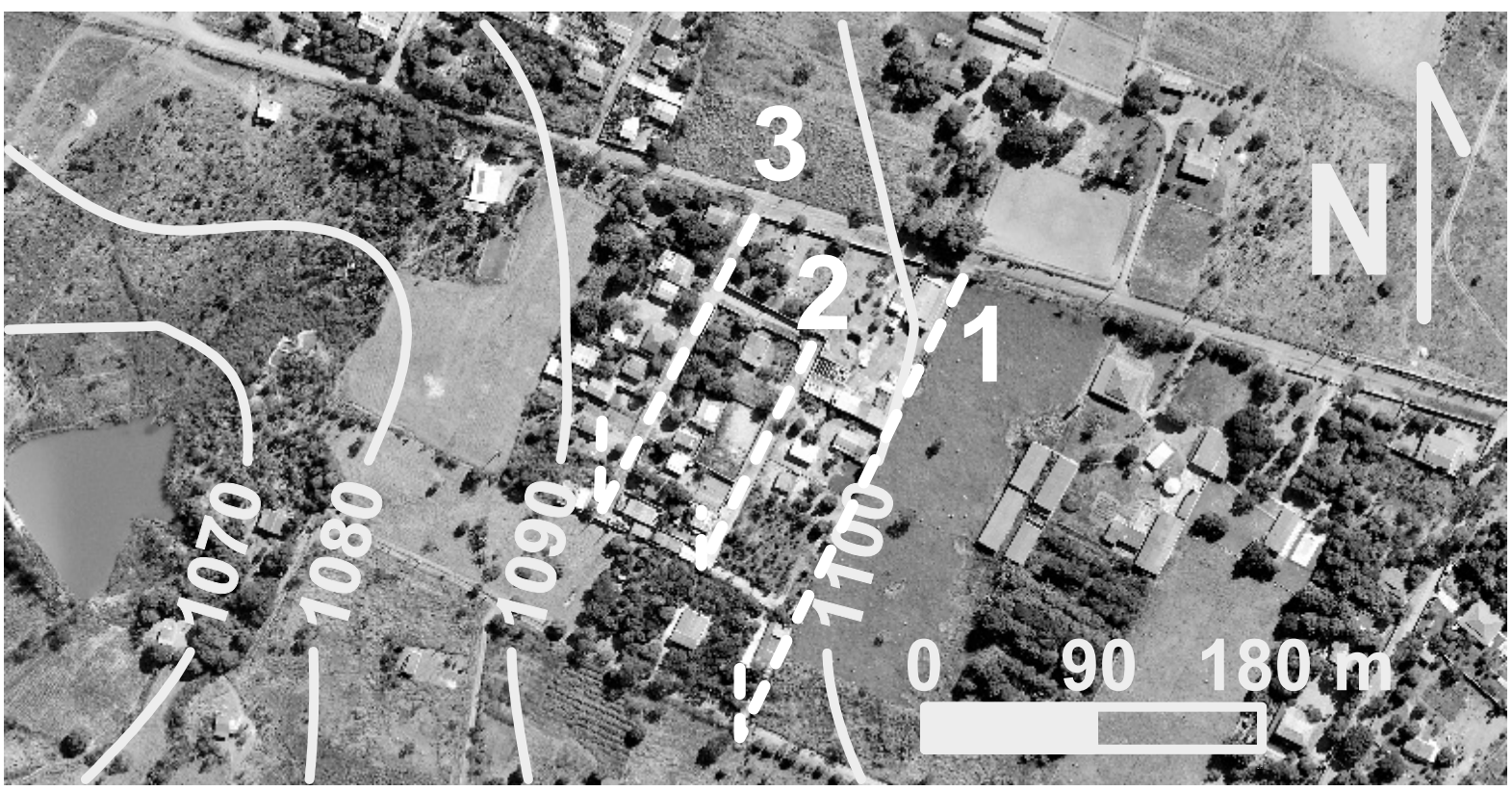

Figure 4 - Detailed study area showing the geophysical survey lines (lines 1, 2 and 3). Image source: SEDHAB (2012).

this spot is located downstream from the studied contamination source. Thus, detecting contaminant plume on this line may be an indicator of another contamination source in addition to the cesspool associated with the meat processing unit.

A plume of contamination was observed at 20 meters in line 2, which corresponds to the pollutant propagation following the flow of the groundwater. Line 3 shows specific regions of low resistivity at 95 and 120 meters, where the cesspools/cisterns of residential lots are located. Apparently, the effluent has been accumulating in the tanks as the water is withdrawn.

Although the resistivity sections can be examined individually, the three images were grouped for the analysis. Therefore, the first step was to standardize the scales of the figures to highlight the anomalous resistivity values, which are linked to the simultaneous spread of the effluent in the saturated zone in three sections (Figs. 5, 6 and 7). The RES2DINV output files, in figure format, were exported to Windows Paint software (Microsoft) for vectorization (Figs. 8, 9 and 10). The three files were then exported to AUTOCAD (Autodesk) where the anomalies contours were georeferenced and joined to generate a solid, whose shape must in principle be related to the shape of the contamination plume that spreads in the saturated zone (Figs. 11, 12 and 13).

The images of Figures 11, 12 and 13 show a low resistivity zone in a region not compatible with what would be expected. The groundwater contamination was detected in February 2009, and after that the pollution-generating activities were interrupted.
In January 2011, a geophysical survey was carried out approximately 18 months after the underground contaminant disposal ceased. Although there are no data on the ability of the aquifer to return to its initial condition, it was expected that due to the time elapsed, the resistivity difference between the contaminated and non-contaminated areas would be smaller. Another feature that draws attention in these images is the point-source aspect of the upstream edge of the possible contamination plume (Fig. 13). Considering only the images of this possible plume, it is possible to conclude that it originates at 80 meters from Line 1 and propagates towards Line 3 . The point-source of contaminant identified and sealed in 2009 is 40 meters downstream of Line 1 and thus, the results lead to the assumption that there must be another source of contamination beyond the one identified in 2009 and that the effluent was being discharged until the date of the geophysical survey.

\section{CONCLUSIONS}

The geophysical survey performed in the study area was suitable for viewing the plume of contaminants originating from the meat processing unit. A plume of contaminant was observed and expected downstream the company site; however, another plume observed upstream may indicate another point of effluent discharge, unknown at the time of the geophysical survey. The image processing to view the shape of the plume in three dimen- 


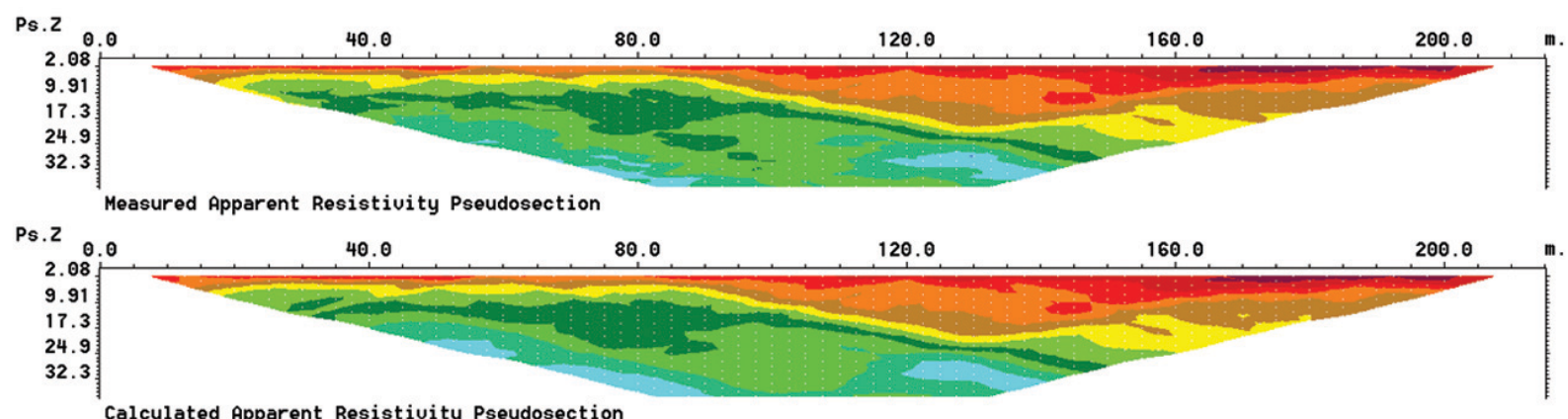

Calculated Apparent Resistivity Pseudosection

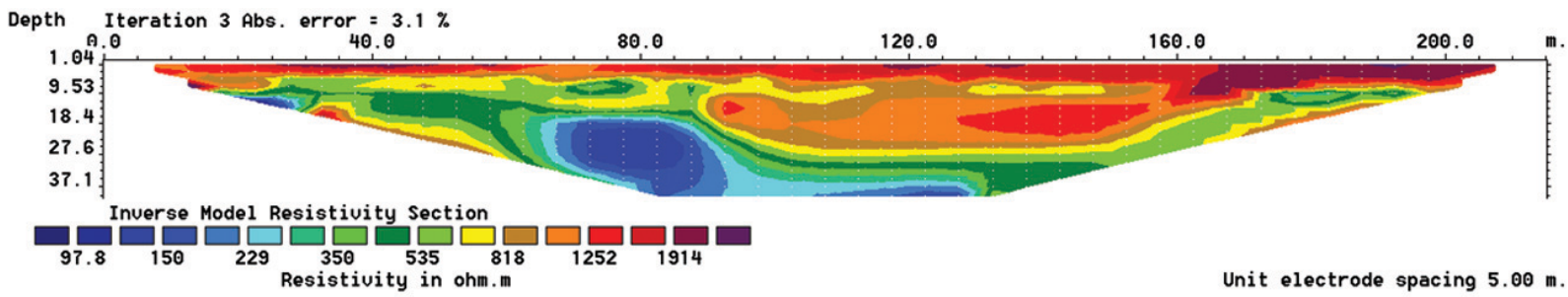

Figure $\mathbf{5}$ - Line 1.
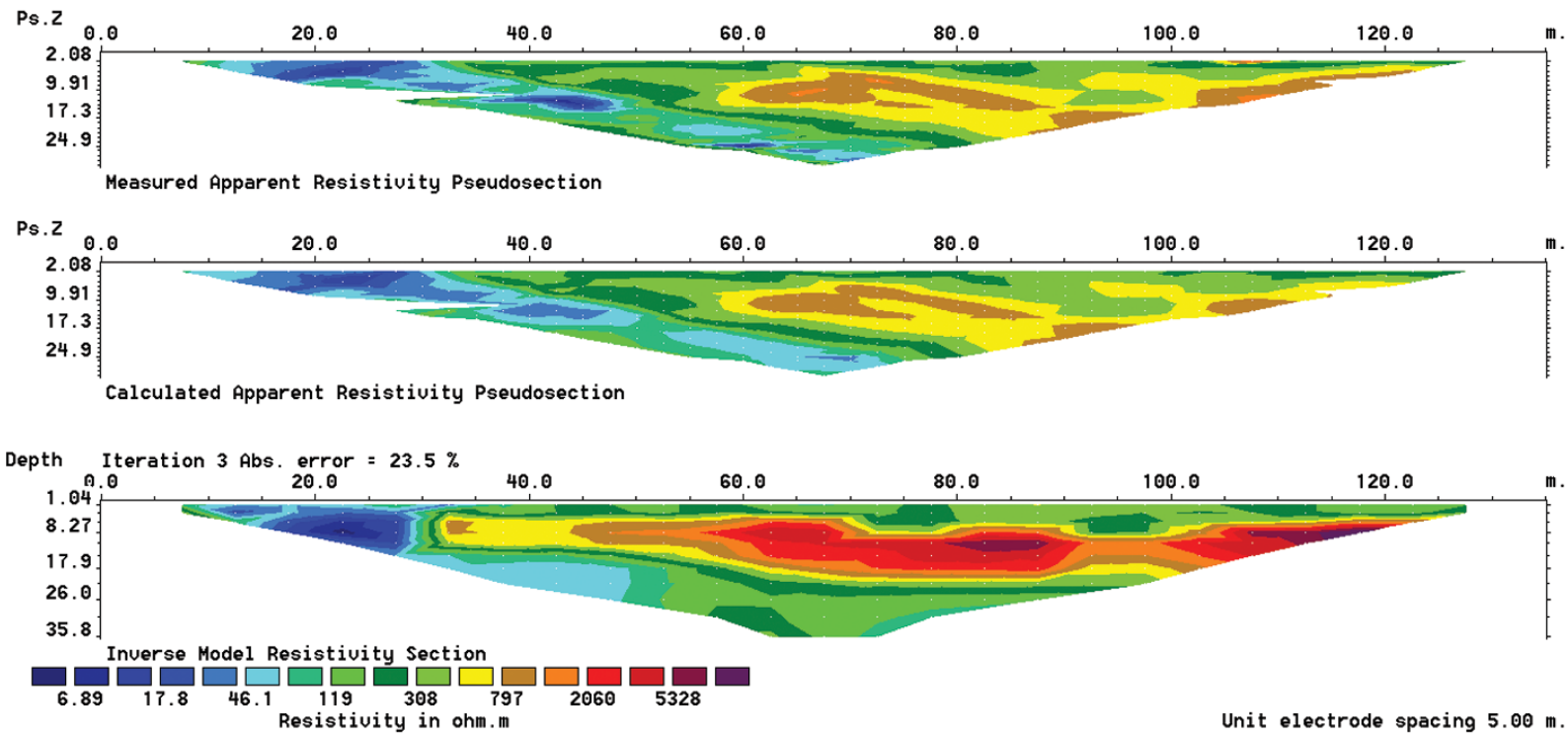

Figure 6 - Line 2.

sions allowed a better assessment of the contamination's origin and pathway. In the light of the new evidence, new field investigation should be conducted to determine other likely sources of contamination and also further geophysical surveying to better define the shape of the plume.

\section{ACKNOWLEDGEMENTS}

The authors are thankful to ADASA - Agência Reguladora de Águas, Energia e Saneamento Básico do Distrito Federal; the
Laboratory of Applied Geophysics, Universidade de Brasília; the Technician João Moreira Pacheco and Professor Welitom Rodrigues Borges of the Universidade de Brasilia.

\section{REFERENCES}

CAMPOS JEG \& FREITAS-SILVA FH. 1998. Hidrogeologia do Distrito Federal. In: Inventário Hidrogeológico e dos Recursos Hídricos Superficiais do Distrito Federal. Brasília, Instituto de Ecologia e Meio Ambiente do Distrito Federal/Universidade de Brasília. 66 pp. 

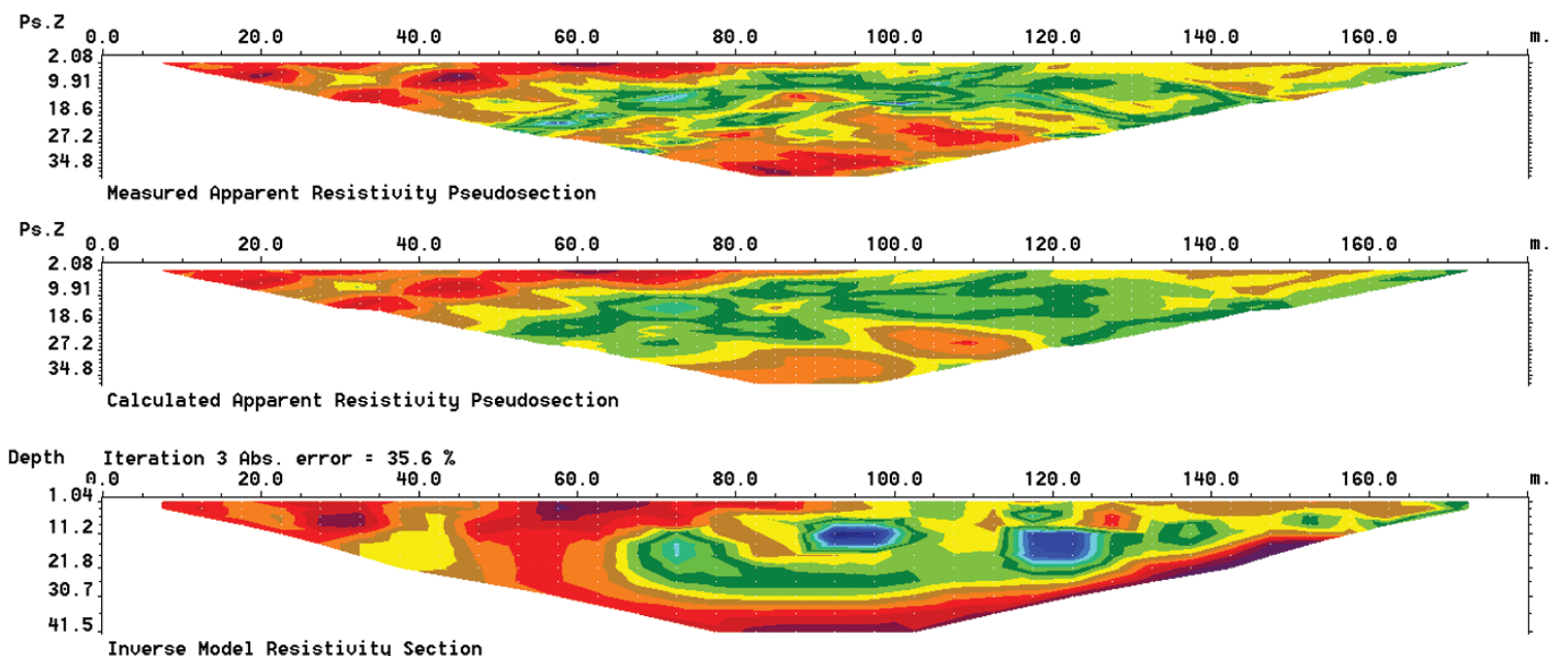

Inverse Model Resistivity Section

${ }_{2.28}{ }_{5.70} \square_{14.2} \square_{35.6}{ }_{88.8} \square_{222} \square_{554} \square_{1382}$

Resistivity in ohm.m

Unit electrode spacing $5.00 \mathrm{~m}$.

Figure 7 - Line 3.

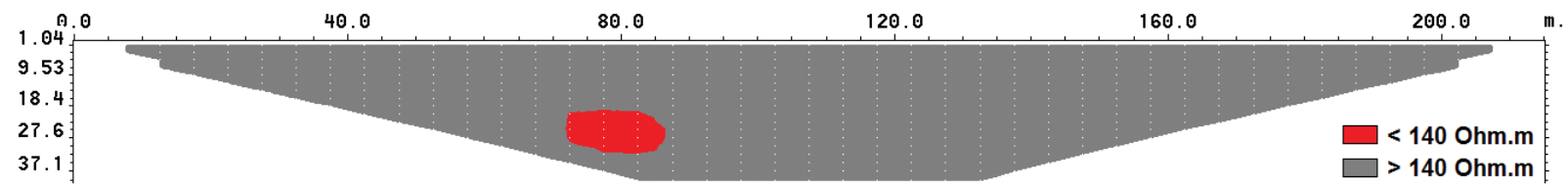

Figure 8 - Line 1.

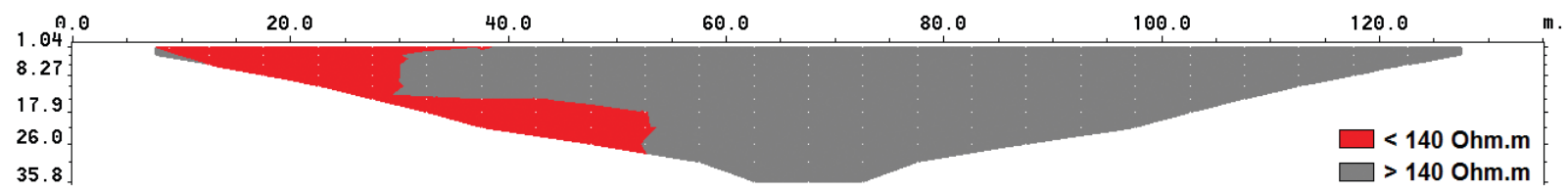

Figure 9 - Line 2.

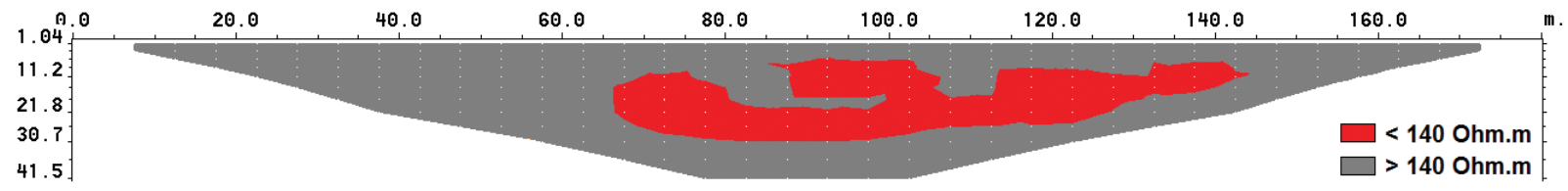

Figure 10 - Line 3.

COSTA AFU \& FERLIN C. 1993. Métodos geofísicos aplicados à definição da contaminação das águas subterrâneas. In: Simpósio Brasileiro de Recursos Hídricos, 10., Porto Alegre, Proceedings... ABRH, 4: 453-461.

COSTA AFU, ZANINI LF, DIAS NL \& CORREA 0. 1995. Metodologia geofísica para detecção de águas subterrâneas; caso do Lixão da Estrada da Palha. A Água em Revista, 3: 24-37.

EDWARDS LS. 1977. A modified pseudo-section for resistivity and in- duced polarization. Geophysics, 42: 1020-1036.

ELLERT N, ROSS S, MENDES JMB \& MARTIN E. 1990. Mapeamento geofísico do lixão de São Carlos. In: Congresso Brasileiro de Águas Subterrâneas, 6., Porto Alegre, Proceedings... ABAS, p. 82-88.

FROHLICH RK, URISH DW, FULLER J \& O'REILLY M. 1994. Use of geoelectrical methods in groundwater pollution surveys in a coastal environment. Journal of Applied Geophysics, 32: 139-154. 


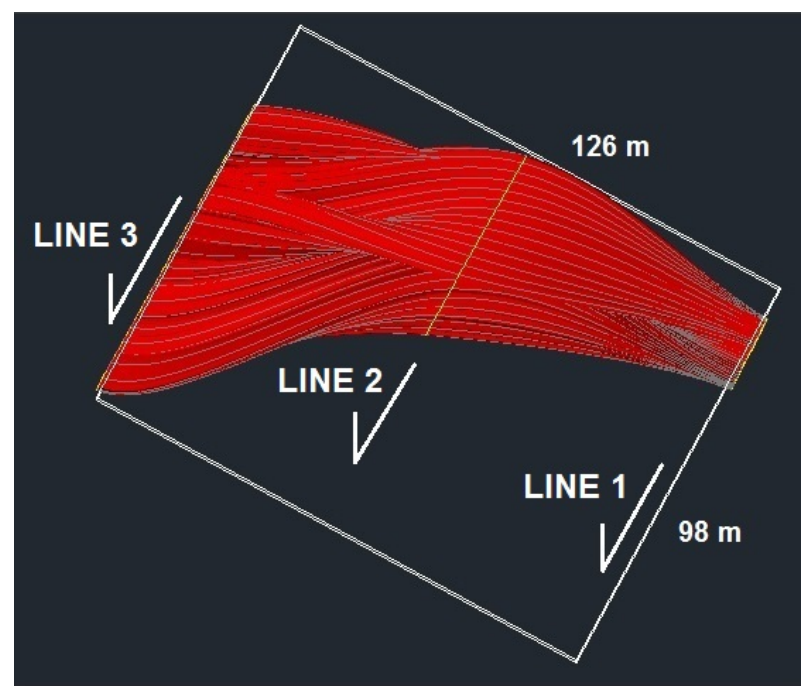

Figure 11 - Top view of the solid associated with the contamination plume.

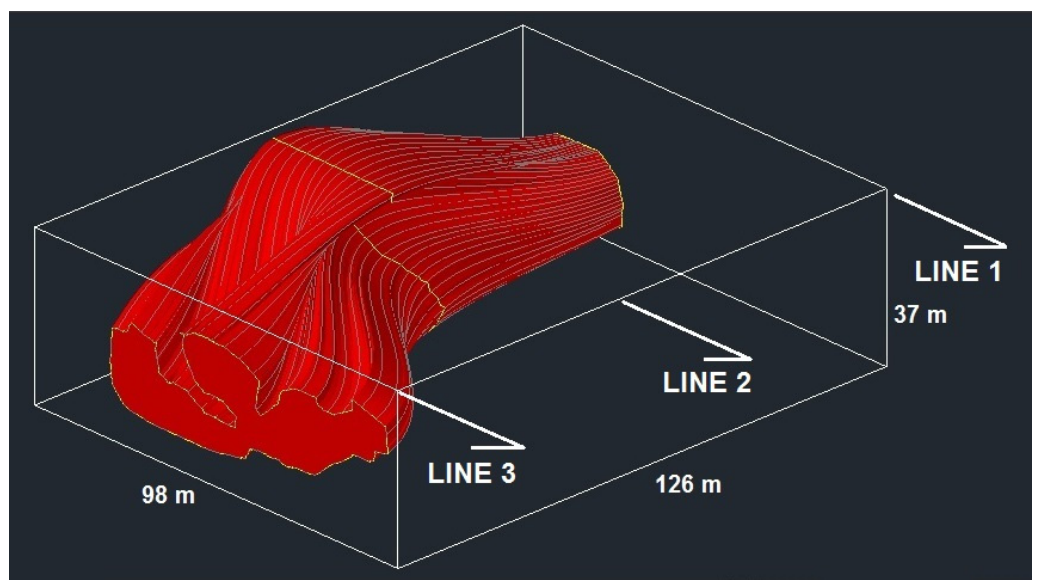

Figure 12 - Downstream to upstream view.

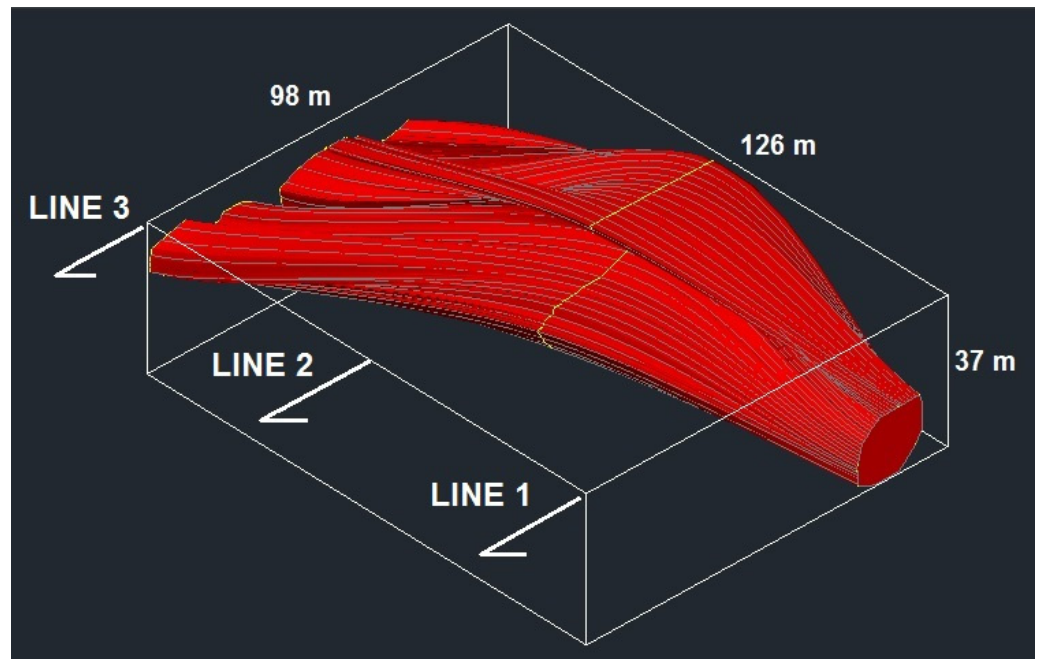

Figure 13 - Upstream to downstream view. 
KELLER GV \& FRISCHKNECHT FC. 1966. Electrical methods in geophysical prospecting. International series of monographs in electromagnetic waves. Pergamom Press, v. 10. $519 \mathrm{pp}$.

LOKE MH \& BARKER RD. 1995. Least-squares deconvolution of apparent resistivity pseudosections. Geophysics, 60: 1682-1690.

LOKE MH \& BARKER RD. 1996. Rapid Least-squares inversion of apparent resistivity pseudosections by a quasi-newton method. Geophysical Prospecting, 44: 131-152.

MATIAS MS, SILVAMM, FERREIRAP \& RAMALHOE. 1994. A geophysical and hydrogeological study of aquifers contamination by a landfill. Journal of Applied Geophysics, 32: 155-162.

MAZAC 0, KELLYWE \& LANDA I. 1987. Surface geoelectrics for groundwater pollution and protection studies. Journal of Hydrology, 93: 277294.

MEJU MA. 1993. Geophysical mapping of polluted groundwater in a closed landfill site. In: International Congress of the Brazilian Geophysical Society, 3., Rio de Janeiro, Proceedings... SBGf, 1: 425-428.

MEJU MA. 2000. Geoelectrical investigation of old/abandoned, covered landfill sites in urban areas: model development with a genetic diagnosis approach. Journal of Applied Geophysics, 44: 115-150.

NASCIMENTO CTC, KOIDE S \& PIRES ACB. 1999a. Contaminação do subsolo monitorada por resistividade elétrica. In: International Congress of the Brazilian Geophysical Society, 6., Rio de Janeiro, Proceedings... SBGf, CD-ROM.

NASCIMENTO CTC, KOIDE S, PIRES ACB \& MELLO GA. 1999b. Pseudo-seç̃es elétricas na avaliação da contaminação do subsolo. Revista Brasileira de Geociências, 29: 621-626.

ORELLANA E. 1972. Prospeccion Geoelectrica en Corriente Continua. Madrid, Paraninfo, $523 \mathrm{pp}$.

PARKHOMENKO El. 1967. Electrical properties of rocks. KELLER GV (Ed.). Translated from Russian, Plenum Press, New York, 314 pp.

SEDHAB. Secretaria de Estado de Habitação, Regularização e Desenvolvimento Urbano. 2012. Ortofotocarta 132. Brasília, Distrito Federal. Available on:

$<$ http://www.sedhab.df.gov.br/downloads/suplan/index_sirgas.htm>. Access on: Nov. 19, 2012

TELFORD WM, GELDART LP, SHERIFF RE \& KEYS DA. 1985. Applied Geophysics. Cambridge, Cambridge University Press, 860 pp.

VAN NOSTRAND R \& COOK KL. 1966. Interpretation of Resistivity Data. Geological Survey Professional Paper 499. Washington, United States Geological Survey, 310 pp.

\section{NOTES ABOUT THE AUTHORS}

Rafael Machado Mello graduated in Biology at the Centro Universitário de Brasília (2004). Holds a M.Sc. in Environmental Technology and Water Resources (UnB - 2013). Currently, works as Executive Manager of ADASA - Agência Reguladora de Águas, Energia e Saneamento Básico (Regulatory Agency for Water, Energy and Sanitation) of the Distrito Federal.

Carlos Tadeu Carvalho do Nascimento holds a degree in Geology (UnB - 1993), Master in Environmental Technology and Water Resources (UnB - 1998) and a Ph.D. in Geology (UnB - 2003). Currently, works as assistant professor at the Universidade de Brasília, in Planaltina. Has experience in Geosciences with emphasis on Applied Geophysics, working mainly in the area of environment.

Sergio Koide holds a degree in Civil Engineering from the Universidade de Brasilia (UnB - 1975), specialization in Pipelines and Terminals Engineering from Petrobras (1976), Master in Civil Engineering (Water Resources) from COPPE-UFRJ (1984) and Ph.D. (water) from the Imperial College - University of London (1990). Currently, works as Associate Professor at the Universidade de Brasilia. Has experience in Sanitary Engineering with emphasis on Water Resources, more specifically: surface and groundwater hydrology (quantity and quality), contamination, and water supply networks (losses and contamination).

João Cândido Magalhães is an undergraduate student in Geophysics from the Universidade de Brasília, and works with geophysical data processing and CAD (computer aided design) software. 